European Journal

of Management Issues

Volume 27(1-2), 2019, pp.36-45

DOI: $10.15421 / 191905$

Received: 21 October 2018

Revised: 14 February 2019; 23 April 2019

Accepted: 01 June 2019

Published: 25 June 2019

\title{
Entrepreneurship strategy for improving business performance using internet technology-based business application
}

\section{M.N. Utomo M. Ariani", J. Safitri\#, K. Kaujan ${ }^{\# \#}$}

Purpose - to conduct an empirical test over the effect of entrepreneurship competency on business performance using Internet technologybased business applications.

Design/Method/Approach. The research population is from small-and-medium Enterprises (SMEs) in the city of Tarakan. The determined sample is based on the observed area; hence, the technique is called probability sampling area. The data analysis technique is Partial Least SquareStructural Equation Modelling (PLS-SEM), run by WarpPls 6.0.

Findings. This research's results indicate that entrepreneurship competency has a positive impact on Internet technology-based business applications. Besides, internet technology-based business application mediates the effect of entrepreneurship competency on business performance.

Theoretical implications. The results support the Resource-Based View Theory, stating that the competitive advantage of an enterprise is derived from its unique resource.

Practical implications. Internet technology-based business applications can be used as entrepreneurship strategies to develop business performance.

Originality/Value. The originality of this research is the internet technology-based business application as a mediating variable between entrepreneurship competence and business performance.

Research limitations/Future research. The research has its limitations; it only uses limited SME research samples in the city of Tarakan. Future research can expand the sample through other Indonesian cities.

Paper type - empirical.

Keywords: entrepreneurship; competency; SMEs; internet technology; online business. based business application. European Journal of Management Issues, 27(1-2), 36-45. doi:10.15421/191905. 


\section{Підприємницька стратегія підвищення ефективності бізнесу на основі Інтернет-технологій з використанням бізнес-додатків}

\section{Мохамад Нур Утомо Мейлія Аріані", Юлія Caфimpi\#, Кауджкан Кауджкан}

\author{
‡університет Борнео Таракан, \\ Таракан, Індонезія, \\ \#університет проф. Д-ра Моестопо (Релегійний), \\ Джакарта, Індонезія, \\ \#Економічний коледж Фонду Інституту розвитку \\ індонезійського підприємниитва у Джакарті \\ (STIE IPWIJA), Джакарта, Індонезія, \\ f\#\#університет Борнео Таракан, \\ Таракан, Індонезія
}

Мета роботи - провести емпіричну перевірку впливу підприємницької компетентності на ефективність бізнесу 3 використанням бізнес-додатків на базі Інтернет-технологій.

Аизайн/Метод/Підхід дослідження. Дослідницька група представники малих та середніх підприємств (МСП) у місті Таракан. Визначений зразок ґрунтується на спостережуваній площі; застосована методика - метод області імовірнісної вибірки. Метод аналізу даних - часткове моделювання квадратних структурних рівнянь (PLS-SEM), розроблене WarpPls 6.0.

Результати дослідження. Показано, що компетентність підприємництва має позитивний вплив на бізнес-додатки, засновані на Інтернет-технологіях. Крім того, бізнес-додаток на базі Інтернет-технологій опосередковує вплив компетентності підприємництва на ефективність бізнесу.

Теоретичне значення дослідження. Результатами дослідження підтверджено теорію поглядів на основі ресурсів та заявлено, що конкурентна перевага підприємства походить з його унікального ресурсу.

Практичне значення дослідження. Бізнес-додатки, засновані на Інтернет-технологіях, можна застосувати як стратегії підприємництва для підвищення ефективності бізнесу.

Оригінальність/Цінність/Наукова новизна дослідження. Оригінальність цього дослідження полягає у характеристиці бізнес-додатків, що базуються на Інтернет-технологіях, як опосередкованих змінних між компетенцією підприємництва та результатами бізнесу.

Обмеження дослідження/Перспективи подальших досліджень. Дослідження має свої обмеження, у ньому використано лише обмежені данні про малий та середній бізнесу у місті Таракан. У майбутніх дослідженнях вибірка може бути розширена у бік інших міст Індонезії.

Тип статті - емпіричний.

Ключові слова: підприємництво; компетентність; МСП; Інтернеттехнології; Інтернет-бізнес.

\section{Предпринимательская стратегия повышения эффективности бизнеса на основе интернет-технологий с использованием бизнес-приложений}

\author{
Мохамад Нур Утомо , \\ Мейлия Ариани", \\ Юлия Cафитри"\#, \\ Каужан Каужан
}

\author{
ұуниверситет Борнео Таракан, \\ Таракан, Индонезия, \\ \#университет проф.Д-ра Moестопо (Религиозный), \\ Джакарта, Индонезия, \\ \#Экономический колледж Фонда Института развития \\ индонезийского предпринимательства в Джакарте \\ (STIE IPWIJA), Джакарта, Индонезия,

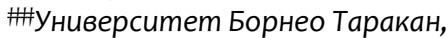 \\ Таракан, Индонезия,
}

Цель работы - провести эмпирическую проверку влияния предпринимательской компетентности на эффективность бизнеса с использованием бизнес-приложений на основе Интернет-технологий.

Дизайн/Метод/Подход исследования. Исследовательская группа - представители малых и средних предприятий (МСП) в городе Таракан. Определенный образец основан на наблюдаемой области; использованная методика метод области вероятностной выборки. Метод анализа данных - это моделирование уравнений частичных наименьших квадратов (PLS-SEM), разработанное WarpPIs 6.0.

Результаты исследования. Показано, что предпринимательская компетентность положительно влияет на бизнесприложения, основанные на интернет-технологиях. Кроме того, бизнес-приложения, основанные на интернеттехнологиях, опосредуют влияние предпринимательской компетентности на эффективность бизнеса.

Теоретическое значение исследования. Результатами исследования подтверждается теория представления на основе ресурсов и утверждается, что конкурентное преимущество предприятия основано на его уникальном ресурсе.

Практическое значение исследования. Бизнес-приложения, основанные на интернет-технологиях, могут использоваться как предпринимательские стратегии для повышения эффективности бизнеса.

Оригинальность/Ценность/Научная новизна исследования. Оригинальность этого исследования заключается в характеристике бизнес-приложений, основанных на интернет-технологиях, как посредниках между предпринимательской компетенцией и эффективностью бизнеса.

Ограничение исследования/Перспективы дальнейших исследований. Исследование имеет свои ограничения; он использует только ограниченные исследовательские данные о МСП в городе Таракан. Будущие исследования могут расширить выборку из других индонезийских городов.

Тип статьи - эмпирический.

Ключевые слова: предпринимательство; компетенция; МСП; Интернет-технологии; Интернет-бизнес. 


\section{Introduction}

ntrepreneurship culture is a fundamental tool to improve the E social and economic standards of the nation (Roblesa \& Rodrigueza, 2015). Developing this entrepreneurship culture, therefore, is important to create economic growth. Entrepreneurship success is determined by an entrepreneur's competency, and an entrepreneur's competency directly affects business performance success (Camuffo, Gerli, \& Gubitta, 2012). Competency, knowledge, creativity, imagination, and ability to capture the opportunity are important factors that affect business success not only now but also in the future; and all of them represent incentives of the entrepreneurs to develop their riches (Zahra, Filatotchev, \& Wright, 2009). Previous researches illustrate that entrepreneurship competency has a positive effect on business performance (Ahmad, Suseno, Seet, Susomrith, \& Rashid, 2018; Barazandeh, Parvizian, Alizadeh, \& Khosravi, 2015; Pamela, Pambudy, \& Winandi, 2016).

On the other hand, the advance of technology has changed the economic image and affected the dynamics of a business environment. Following globalization, Small-and-Medium Enterprises find the business environment becoming more competitive and difficult for them to keep and improve business performance (Kraus, Rigtering, Hughes, \& Hosman, 2012). Some literature sources explain that a determinant factor to entrepreneurship success is technology. The entrepreneurs of Small-and-Medium Enterprises' should realize that the change of human habit or lifestyle can affect the business strategy that they apply. In the digital era, interaction with internet technology has become a lifestyle and even a habit of daily human activity.

The survey conducted by Asosiasi Penyelenggara Jasa Internet Indonesia (APJII) or Association of the Indonesian Internet Service Provider indicates that the use of the internet among Indonesians has been significantly increasing in a few years. The Internet user value was only about $7.8 \%$ of Indonesians in 2005 , and this number increased to $34.9 \%$ in 2014 and became $51.8 \%$ in 2016(APJII, 2016). Based on the performance report retrieved from the Ministry of Communication and Informatics, the cellular gadgets entering Indonesia had reached about 126\% in 2016 (Kemkominfo, 2016). Data collected by the Ministry show that internet technology and cellular gadgets are growing fast and changing the way of how entrepreneurs usually run the business. Internet technology allows businesses to automate their manual operations and process of the information faster (APJII, 2016).

Internet technology has fundamentally changed the business paradigm and becomes more integrated into the marketing function of a business (Prasad, Ramamurthy, \& Naidu, 2001). Internet marketing then emerges as one of the thrusting forces that stimulate enterprises to build a good relationship with customers (Strauss, El-Ansary, \& Frost, 2003). Entrepreneurs, therefore, are expected to integrate their competency by internet technology whilst managing business. Rosalind Jones, Alford, and Wolfenden (2015) have found that Small-and-Medium Enterprises (SMEs) of tourism in Britain are enthusiastic to adopt internet technology and willing to learn benefits from digital marketing. The Internet has provided them the opportunity of innovation to the scale that they could not have imagined before. For example, digital marketing provides ultimate information access that helps SMEs to define market targets faster. Other researches declare that the internet has proved to be effective as a marketing tool of SMEs (Chaston \& Mangles, 2003; Datta \& R, 2005; Mujiyana, Sularto, \& Mukhyi, 2012; Reimers, Chao, \& Gorman, 2016). It indeed provides the opportunity for SMEs and entrepreneurs to promote their products and develop their business via the internet.

The objective of this research is to examine the relationship between the competency of entrepreneurs and internet technology-based business applications when entrepreneurs attempt to develop business performance. The research was conducted at Small-and-Medium Enterprises (SMEs) in the city of Tarakan, Indonesia. This research's results show that entrepreneurship competency positively affects internet technology-based business applications. Indeed, internet technology-based business application seems to mediate the effect of entrepreneurship competency on business performance. This paper is divided into seven sections. The second section explains the literature review and hypothesis development. The third section is on methodology. The fourth section concerns the result, while the fifth provides discussion. The sixth and seventh sections are conclusions and limitations.

\section{Literature Review and Hypothesis Development}

\subsection{The Effect of Entrepreneurship Competency on Internet Technology-Based Business Application}

he extent of internet technology adoption by entrepreneurs $\langle$ T in their business activity is affected by several factors, such as entrepreneurship competency, customer habit, supplier or intermediary, competition level, and product characteristics (Howcroft \& Durkin, 2000). Technology is a method to process things to obtain cost and time efficiencies, which later results in more qualified products. The bases of technology creation include market demand, problems solution, science application, improvement of effectiveness and efficiency, and modernization (Marti'ah, 2017). Internet technology-based business application is a process of establishing business innovation when entrepreneurs adapt and involve internet technology as their expectancy base to create a proper innovative strategy to improve business performance. Some empirical studies support the effect of entrepreneurship competency on internet technology-based business applications.

McGowan and Durkin (2010) explored whether entrepreneurship competency in small enterprises adopted and utilized internet potentials in developing and supporting a good relationship among customers. This relationship is the key factor and one of the main focuses in marketing literature, especially when discussing the relationship between supplier and customer or buyer. A qualitative methodology was applied to examine the features and characteristics of challenges dealt with by 30 individuals using the internet. The results of this examination indicate that entrepreneurship competency stimulates entrepreneurs adopting the internet to develop their business. The ultimate output of this research is a more comprehensive insight of competency, which is called as entrepreneurial small firm (ESF) that represents an internet marketing spectrum.

Ezenwafor, Onokpaunu, and Nna-Emmanuel (2017) observed a population of 200 entrepreneurs in Delta North Senatorial District of Delta State. Their study revealed that Delta State entrepreneurs assume themselves as incompetent to use online social media as a marketing tool. They benefit from online social media as the marketing method, by greater success in their business, improving customer awareness to their products, and increasing customer loyalty, which further produces a higher sale cycle. This research recommends successful digital entrepreneurs to advise the novices and potential entrepreneurs to keep them informed about competencies they need to have for successful marketing via online social media.

Marti'ah (2017) carried out a descriptive review of the business process (entrepreneurs) using the technology base and elaborated the review under the education perspective. This review described middle and small enterprises that apply technology through motivation, ownership, management, employment, etc. Technopreneurship can be introduced through the education world as a transformation tool, or precisely as a science to developing entrepreneurship using technology base. 
According to the empirical researches above and some elaborations, the following hypothesis is then proposed:

H1: Dynamic entrepreneurship competency has a positive effect on entrepreneurs to adopt internet technology-based business applications.

\subsection{The Effect of Internet Technology-Based Business Application on Business Performance}

he application of internet technology (including website, T email, blog and online social media) into a business allows small entrepreneurs to change the way they communicate with the customers, how they market their products and services, and how they interact with customers to develop a better relationship. The change facilitated by internet media might deliver benefits to entrepreneurs, either through sale, intention, customers' attention, innovation, etc.

Some empirical reviews have found a positive effect of internet technology-based business applications on business performance. Wade, Johnston, and McClean (2004) conducted a study to explore the effect of the post-adoption of Internet Business Solution (IBS) on business value creation. Business value is measured by income, direct and indirect costs, and investment satisfaction. The sample included 254 Small-and-Medium Enterprises in Canada and the United States. The results of this research show that business value can be significantly improved by applying Internet Business Solution (IBS). Moreover, McGowan and Durkin (2010) perceived that the main reason of why Small-and-Medium Enterprises' entrepreneurs adopt internet technology-based business application is to collect information faster and to improve their business performance.

Doherty, Ramsey, Harrigan, and lbbotson (2016) employed a qualitative method to explain the main issues related to Small-andMedium Enterprises (SMEs) in Ireland. Their study explored how SMEs' acceptance of internet technology is and its impact on them. The study also conducted further investigation on how new internet technology is adopted. The adoption of broadband internet technology by SMEs has successfully increased efficiency and helped them develop a strategy daily. The manager/owner of SMEs is a decision-maker, and mostly they indicate that the broadband internet technology (including website, email, blog, and online social media) can improve the business image for the better. The effect of online trading through e-commerce can reveal a new international market for SMEs. Some SMEs have gradually applied this technology, but in other SMEs, technology is successfully increasing efficiency and productivity by giving an efficient or real-time way of communication.

By taking into account the studies above, two hypotheses are then generated, which can be presented as follows:

H2: Internet technology-based business application increases business performance.

H3: Internet technology-based business application is the effect mediator of entrepreneurship competency on business performance.

All the hypotheses proposed are further arranged to constitute an empirical research model to answer the research problem. This Empirical Research Model is depicted in Fig. 1.

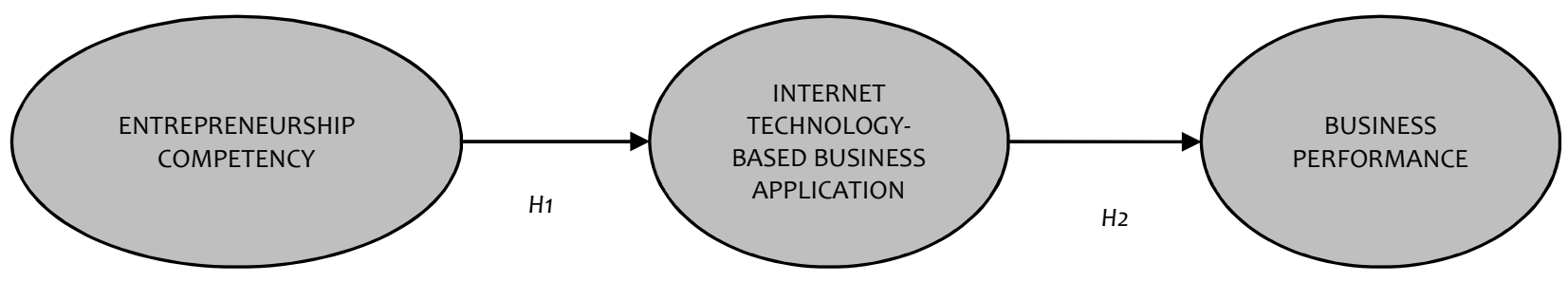

*Source: compiled by Authors.

Fig 1. Empirical Research Model ${ }^{*}$

\section{Methods and Data}

\subsection{Research Variable}

here are three (3) latent variables observed and measured in $\langle$ T this research. These are entrepreneurship competency as an independent/exogenous variable, internet technology-based business application as mediation variable, and business performance as a latent/unobserved (unmeasured) variable. All these variables are proxied by respondents' perceptions on indicators of each variable. Both variables and their indicators are elaborated in the following Table 1.

\subsection{Population and Sample}

he research population is all from small-and-medium T Enterprises (SMEs) in the city of Tarakan. Some reasons why the city of Tarakan became this research's area are: a) the city of Tarakan location bordering Malaysia and Brunei Darussalam, it is the potential for trade among countries as indicated in the city of Tarakan, many goods originating from Malaysia are imported, and conversely, there are many goods from Tarakan in Malaysia, b) the city of Tarakan is a stopover city and serves as an entry point for people from all regions of North Borneo (Bulungan regency, Nunukan Regency, Tana Tidung Regency, and Malinau regency), and c) the city of Tarakan is known as a service business city, which encourages the growth of SMEs more than other cities and districts in Northern Borneo.

The determined sample is based on area, and hence, the sampling technique is called an area probability sampling. The observed area include several districts, namely Central Tarakan, West Tarakan, East Tarakan, and North Tarakan. The research sample is SMEs' entrepreneurs based on the definition given by No.20/2008 Law and BPS. One hundred (100) respondents become the sample and each has a different business, such as trade, service, or home industry. The data collection technique involves primary data extraction. Field study is carried out at a research location with questionnaires distribution. Respondents (SMEs' entrepreneurs) were required to answer the questionnaire, and their answers provided data for analyzes. The obtained data are categorized into several time dimensions, making the data cross-sectional. 
Table 1

Variables and Indicators

\begin{tabular}{|c|c|c|}
\hline Latent Variable & Indicator of Variable & $\begin{array}{l}\text { Reference } \\
\text { Source }\end{array}$ \\
\hline $\begin{array}{l}\text { Entrepreneurs } \\
\text { hip } \\
\text { Competency } \\
\text { (Exogenous } \\
\text { Latent) }\end{array}$ & $\begin{array}{l}\text { 1. Risk Control } \\
\text { 2. Autonomy } \\
\text { 3. Searching and } \\
\text { Analyzing Information } \\
\text { 4. Communication } \\
\text { 5. Dynamic } \\
\text { 6. Building the Social } \\
\text { Network } \\
\text { 7. Change Management } \\
\text { 8. Initiative } \\
\text { 9. Innovation } \\
\text { 10. Integrity } \\
\text { 11. Leadership } \\
\text { 12. Result Orientation } \\
\text { 13. Negotiation } \\
\text { 14. Problem Solving Skill } \\
\text { 15. Responsibility }\end{array}$ & $\begin{array}{l}\text { Roblesa \& } \\
\text { Rodrigueza, } \\
2015)\end{array}$ \\
\hline $\begin{array}{l}\text { Internet } \\
\text { Technology- } \\
\text { Based Business } \\
\text { Application } \\
\text { (Intervening } \\
\text { Latent) }\end{array}$ & $\begin{array}{l}\text { 1. Online } \\
\text { Communication Channel } \\
\text { 2. Online Promotion } \\
\text { Channel } \\
\text { 3. Online Supply } \\
\text { Distribution Channel } \\
\text { 4. Online Sale Channel } \\
\text { 5. Online Transaction } \\
\text { Channel }\end{array}$ & $\begin{array}{l}\text { (Peterson, } \\
\text { Balasubrama } \\
\text { nian, \& } \\
\text { Bronnenberg, } \\
\text { 1997) }\end{array}$ \\
\hline $\begin{array}{l}\text { Business } \\
\text { Performance } \\
\text { (Endogenous } \\
\text { Latent) }\end{array}$ & $\begin{array}{ll}\text { 1. } & \text { Profit Growth } \\
\text { 2. } & \text { Sale Growth } \\
\text { 3. Capital Growth } \\
\text { 4. Efficiency } \\
\text { 5. } \\
\end{array}$ & $\begin{array}{l}\text { (Meutiaa \& } \\
\text { Ismail, 2012; } \\
\text { Sidik, 2012) }\end{array}$ \\
\hline
\end{tabular}

*Source: Results of theoretical studies and empirical reviews on hypotheses.

\subsection{Data Analysis Technique}

he combination of Partial Least Squares (PLS) and Structural $\langle$ T Equation Modelling (SEM) (PLS-SEM) was used to analyze research data, and this technique was processed by the WarpPLS version 6.0 computer program. The analysis involves several tests, such as measurement test (validity and reliability), Goodness-of-Fit test, mediation test, and hypothesis test. Research hypotheses are tested using the following equation:

$$
\begin{aligned}
& \mathrm{IBb}=\alpha_{1}+\beta_{1} \mathrm{Ec}+\varepsilon_{1}, \\
& \mathrm{Bp}=\alpha_{2}+\beta_{21} \mathrm{IBb}+\varepsilon_{2},
\end{aligned}
$$

wherein IBb - Internet Technology-Based Business Application; Ec - Entrepreneurship Competency;

BP - Business Performance.

\section{Results}

\subsection{Descriptive Statistic}

espondents' perception of variables observed is understood $\langle\mathbf{R}\rangle$ via interval criteria $\left[\frac{5-1}{3}\right]=1,33$. Sugiyono (2012) states that the criteria of value interpretation can be arranged into a few categories:

$$
\begin{array}{ll}
1,00-2,33 & =\text { Low } \\
2,34-3,66 & =\text { Medium } \\
3,67-5,00 & =\text { High }
\end{array}
$$

Each variable to be described in the following sections.

\subsubsection{Entrepreneurship Competency}

ntrepreneurship competence is measured by fifteen (15) E indicators. Under the survey result and descriptive analysis, the index of entrepreneurship competency is depicted in Table 2.

\section{Descriptive Statistic of Entrepreneurship Competency}

\begin{tabular}{c|l|c}
\hline No & \multicolumn{1}{|c|}{ Indicator } & Average Rate \\
\hline 1. & Risk Control & 4,08 \\
\hline 2. & Autonomy & 3,82 \\
\hline 3. & Searching and Analyzing Information & 4,08 \\
\hline 4. & Communication & 4,29 \\
\hline 5. & Dynamic & 3,94 \\
\hline 6. & Building the Social Network & 4 \\
\hline 7. & Change Management & 3,85 \\
\hline 8. & Initiative & 3,95 \\
\hline 9. & Innovation & 3,8 \\
\hline 10. & Integrity & 4,37 \\
\hline 11. & Leadership & 4,29 \\
\hline 12. & Result Orientation & 4,09 \\
\hline 13. & Negotiation & 3,95 \\
\hline 14. & Problem Solving Skill & 4,02 \\
\hline 15. & Responsibility & 4,58 \\
\hline & Total Average Rate & 4,074 \\
\hline source & Primary Data is Processed(2018). \\
\hline
\end{tabular}

Source: Primary Data is Processed (2018).

Table 2 shows that the total average rate of respondents' answers to the variable of entrepreneurship competency is 4,074. The highest average rate is shown by an indicator of responsibility with 4,58 , while the lowest is given by indicator of innovation with 3,8 . Based on the value interpretation of all the indicators, it can be mentioned that the entrepreneurship competence of the respondents is residing in the high category.

\subsubsection{Internet Technology-Based Business Application}

nternet technology-based business application is measured I by five (5) indicators. Based on the result of the survey and descriptive analysis Table 3 was designed to indicate the index of internet technology-based business application.

Table 3

Descriptive statistic of internet technology-based business application

\begin{tabular}{c|l|c}
\hline No & Indicator & Average Rate \\
\hline 1. & Online Communication Channel & 4,17 \\
\hline 2. & Online Promotion Channel & 4,05 \\
\hline 3. & Online Supply Distribution Channel & 3,74 \\
\hline 4. & Online Sale Channel & 3,58 \\
\hline 5. & Online Transaction Channel & 3,2 \\
\hline & Total Average Rate & 3,75 \\
\hline
\end{tabular}

*Source: Primary Data is Processed (2018)

Table 3 indicates that the total average rate of respondents' answers to the variable of internet technology-based business application is 3,75. The highest average rate is given by indicator of the online communication channel with 4,17 , while the lowest is provided by the indicator of the online transaction channel with 3,2 . According to the value interpretation of all indicators, it can be said that internet technology-based business application by the respondents is staying at high category.

\subsubsection{Business Performance}

usiness performance is measured with five (5) indicators. In B pursuance of the result of the survey and descriptive analysis, the index of business performance is presented in Table 4 
Descriptive Statistic of Business Performance*

\begin{tabular}{c|l|c}
\hline No & Indicator & Average Rate \\
\hline 1. & Profit Growth & 3,87 \\
\hline 2. & Sale Growth & 3,9 \\
\hline 3. & Capital Growth & 3,72 \\
\hline 4. & Efficiency & 3,46 \\
\hline 5. & Customer Growth & 3,96 \\
\hline & Total Average Rate & 3,78
\end{tabular}

*Source: Primary Data is Processed (2018).

Table 4 shows that the total average rate of respondents' answers to the variable of business performance is 3,78 . The highest average rate is indicated by the indicator of customer growth with 3,96 , while the lowest is shown by the indicator of efficiency with 3,46 . Given the value interpretation of all indicators, business performance seems to be in the high category.

\subsection{Evaluation of Research Model}

he evaluation of the research model involves two stages, $\langle$ T which start from the evaluation of the measurement model and continues with the evaluation of the structural model. The evaluation process is made by PLS-SEM and WarpPls version 6.o. The algorithm method used in this research to examine the outer model had been available in PLS Model A, and this mode was used because all constructs in this research use reflexive indicators. The inner model has been examined by Mode Linear because the relationship of all constructs in the model is assumed to be linear. The bootstrapping method was used for re-sampling, and it might be the best option for sample size that is equaled to or more than 100 (Sholihin \& Ratmono, 2013).

\subsubsection{Evaluation of Measurement Model}

valuation of measurement model aims to assess the reliability E and validity values of the indicators that constitute latent variables. Based on model conceptualization, all variables in this research are measured with reflexive indicators. Latan and Ghozali (2016) state that the measurement of reliability and validity (outer model) with reflexive indicators must involve the following conditions:

1. Indicator reliability is obtained only if its factor loading value is $>0,7$.

2. Internal consistency's reliability is attained only when composite reliability is $>0,7$.

3. Convergent validity is acquired only if the Average Variance Extracted (AVE) is >0,5.

4. Discriminant validity has prevailed only if Square-Root AVE is > correlation across the constructs.

Result of analysis on indicator reliability of all indicators that explain the research variable is displayed in Table 5.

According to Table 5, there are indicators with factor loading values less than 0,7. All of them are indicators in the variable of entrepreneurship competency:

- Autonomy (EC2) with a factor loading value of 0,579;

- Dynamic (EC5) with a factor loading value of 0,662;

- Change Management (Ec7) with a factor loading value of 0,513;

- Initiative (Ec8) with a factor loading value of 0,496 ;

- Innovation (Ec9) with a factor loading value of 0,571;

- Integrity (Ec10) with a factor loading value of 0,557;

- Result Orientation (Ec12) with a factor loading value of 0,568;

- Negotiation (Ec13) with a factor loading value of 0,672;

- Problem-solving skill (Ec14) with factor loading value of 0.657 .
Factor Loading Values of Indicators of Research Variable*

\begin{tabular}{|c|c|c|c|}
\hline Variable & & Indicator & $\begin{array}{c}\text { Factor } \\
\text { Loading }\end{array}$ \\
\hline \multirow{15}{*}{$\begin{array}{l}\text { Entrepreneurship } \\
\text { Competency (Ec) }\end{array}$} & Ec1 & Risk Control & 0,765 \\
\hline & EC2 & Autonomy & 0,579 \\
\hline & Ec3 & $\begin{array}{l}\text { Searching and } \\
\text { Analyzing } \\
\text { Information }\end{array}$ & 0,762 \\
\hline & Ec4 & Communication & 0,734 \\
\hline & Ec5 & Dynamic & 0,662 \\
\hline & Ec6 & $\begin{array}{l}\text { Building the } \\
\text { Social Network }\end{array}$ & 0,744 \\
\hline & Ec7 & $\begin{array}{l}\text { Change } \\
\text { Management }\end{array}$ & 0,513 \\
\hline & Ec8 & Initiative & 0,496 \\
\hline & Ec9 & Innovation & 0,571 \\
\hline & Ec10 & Integrity & 0,557 \\
\hline & Ec11 & Leadership & 0,733 \\
\hline & Ec12 & $\begin{array}{l}\text { Result } \\
\text { Orientation }\end{array}$ & 0,568 \\
\hline & Ec13 & Negotiation & 0,672 \\
\hline & Ec14 & $\begin{array}{l}\text { Problem Solving } \\
\text { Skill }\end{array}$ & 0,657 \\
\hline & Ec15 & Responsibility & 0,754 \\
\hline \multirow{5}{*}{$\begin{array}{l}\text { Internet } \\
\text { Technology- } \\
\text { Based Business } \\
\text { Application (IBb) }\end{array}$} & IBb1 & $\begin{array}{l}\text { Online } \\
\text { Communication } \\
\text { Channel }\end{array}$ & 0,792 \\
\hline & IBb2 & $\begin{array}{l}\text { Online Promotion } \\
\text { Channel }\end{array}$ & 0,856 \\
\hline & $\mathrm{IBb}_{3}$ & $\begin{array}{l}\text { Online Supply } \\
\text { Distribution } \\
\text { Channel } \\
\end{array}$ & 0,742 \\
\hline & IBb4 & $\begin{array}{l}\text { Online Sale } \\
\text { Channel }\end{array}$ & 0,789 \\
\hline & IBb5 & $\begin{array}{l}\text { Online } \\
\text { Transaction } \\
\text { Channel }\end{array}$ & 0,72 \\
\hline \multirow{5}{*}{$\begin{array}{l}\text { Business } \\
\text { Performance } \\
\text { (Bp) }\end{array}$} & Bp1 & Profit Growth & 0,916 \\
\hline & Bp2 & Sale Growth & 0,907 \\
\hline & $\mathrm{Bp3}$ & Capital Growth & 0,858 \\
\hline & Bp4 & Efficiency & 0,723 \\
\hline & Bp5 & Customer Growth & 0,745 \\
\hline
\end{tabular}

*Source: Primary Data is Processed (2018).

Rule of thumb for measuring reliability and validity of indicators is not included and even eliminated from the process. Therefore, the analysis of reliability and validity only involves three elements, namely factor loading value, composite reliability value, and AVE rate.

The result of each element is elaborated in Table 6.

All indicators in Table 6 are considered as valid because the factor loading value of these indicators is more than 0.7. These indicators also have good indicator reliability. The rate of AVE for each indicator is quite good as the obtained rate is $>0,5$, which thus fulfills the criterion of convergent validity. Composite Reliability of each indicator is also quite good as the attained value is $>0,7$, which thus fulfills the criterion of internal consistency's reliability.

The comparison between Square-Root AVE and Cross-Construct Correlations is clarified in Table 7.

The rate of Square-Root AVE for each construct is higher than cross-construct correlations, and thus, each construct has good discriminant validity (Table 7). 
Factor Loading Value, Composite Reliability, and Average Variance Extracted

\begin{tabular}{|c|c|c|c|c|}
\hline Variable & Indicator & Factor Loading & Composite Reliability & AVE \\
\hline \multirow{6}{*}{$\begin{array}{l}\text { Entrepreneurship } \\
\text { Competency }\end{array}$} & Risk Control (Ec1) & 0.765 & 0.92 & 0.606 \\
\hline & Searching and Analyzing Information (Ec3) & 0.762 & & \\
\hline & Communication (Ec4) & 0.734 & & \\
\hline & Building the Social Network (Ec6) & 0.744 & & \\
\hline & Leadership (Ec11) & 0.733 & & \\
\hline & Responsibility (Ec15) & 0.754 & & \\
\hline \multirow{5}{*}{$\begin{array}{l}\text { Internet Technology-Based } \\
\text { Business Application }\end{array}$} & Online Communication Channel (IBb1) & 0.792 & 0.886 & 0.610 \\
\hline & Online Promotion Channel (IBb2) & 0.856 & & \\
\hline & Online Supply Distribution Channel (Ibb3) & 0.742 & & \\
\hline & Online Sale Channel (Ibb4) & 0.789 & & \\
\hline & Online Transaction Channel (Ibb5) & 0.72 & & \\
\hline \multirow[t]{5}{*}{ Business Performance } & Profit Growth (Bp1) & 0.916 & 0.919 & 0.695 \\
\hline & Sale Growth (Bp2) & 0.907 & & \\
\hline & Capital Growth (Bp3) & 0.858 & & \\
\hline & Efficiency (Bp4) & 0.723 & & \\
\hline & Customer Growth (Bp5) & 0.745 & & \\
\hline
\end{tabular}

Source: Primary Data are Processed (2018).

Square-Root AVE and Cross-Construct Correlations*

\begin{tabular}{|c|c|c|c|c|}
\hline \multirow{2}{*}{ Construct } & \multirow{2}{*}{ Square-Root AVE } & \multicolumn{3}{|c|}{ Correlations } \\
\hline & & $\mathrm{EC}$ & IBB & $\mathrm{BP}$ \\
\hline Entrepreneurship Competency & 0.778 & 1 & 0.552 & 0.592 \\
\hline Internet Technology-Based Business Application & 0.781 & 0.552 & 1 & 0.644 \\
\hline Business Performance & 0.834 & 0.592 & 0.644 & 1 \\
\hline
\end{tabular}

*Source: Primary Data is Processed (2018).

\subsubsection{Evaluation of Structural Model}

valuation of the structural model (inner model) aims to $\langle$ E predict relationships across variables by examining how much variance can be explained to acknowledge the P-value significance (Latan \& Ghozali, 2016). Also, the structural model evaluation is besides useful to explain the need for the test on four hypotheses of this research.

Before the evaluation relationship across variables, the goodnessof-fit must be evaluated first, as indicated by the following Table 8.

Research model has good fit, and it is proved by P-value of $<0.05$ for APC, ARS and AAR, when the value of each is explained as follows: $A P C=0,598, A R S=0,360$ and $A A R S=0,354$. Both AFVIF rates are $<3,3$, meaning that there is no multicollinearity problem across indicators and exogenous variables. The goodness-of-fit rate is $0,479>0,36$, which means that the model's fit is quite good. The rates for SPR, RSCR, SSR, and NLBCDR are mostly equaled to 1 , meaning that there is no causality problem in the model (Latan \& Ghozali, 2016).

The estimated relationship across variables and its variance rates are shown in Table 9.

Fig. 2 illustrates the estimated relationship across variables and their variance rates.

\section{Goodness-of-Fit of Structural Model}

\begin{tabular}{l|c|l}
\hline Criteria & Parameter & Rule of Thumb \\
\hline Average path coefficient (APC) & $0,598 / \mathrm{P}<0,001$ & Acceptable $\mathrm{P}<0,05$ \\
\hline Average R-squared (ARS) & $0,360 / \mathrm{P}<0,001$ & Acceptable $\mathrm{P}<0,05$ \\
\hline Average adjusted R-squared (AARS) & $0,354 / \mathrm{P}<0,001$ & Acceptable $\mathrm{P}<0,05$ \\
\hline Average full collinearity VIF (AFVIF) & 1,834 & acceptable if $<=5$, ideally $<=3,3$ \\
\hline Tenenhaus GoF (GoF) & 0,479 & small $>=0,1$, medium $>=0,25$, large $>=0,36$ \\
\hline Sympson's paradox ratio (SPR) & 1,000 & acceptable if $>=0,7$, ideally $=1$ \\
\hline R-squared contribution ratio (RSCR) & 1 & acceptable if $>=0,9$, ideally $=1$ \\
\hline Statistical suppression ratio (SSR) & 1 & acceptable if $>=0,7$ \\
\hline Nonlinear bivariate causality direction ratio (NLBCDR) & 1 & acceptable if $>=0,7$ \\
\hline
\end{tabular}

${ }^{*}$ Source: Primary Data are Processed (2018).

Result of Estimation on Relationship Across Variables*

Table8 


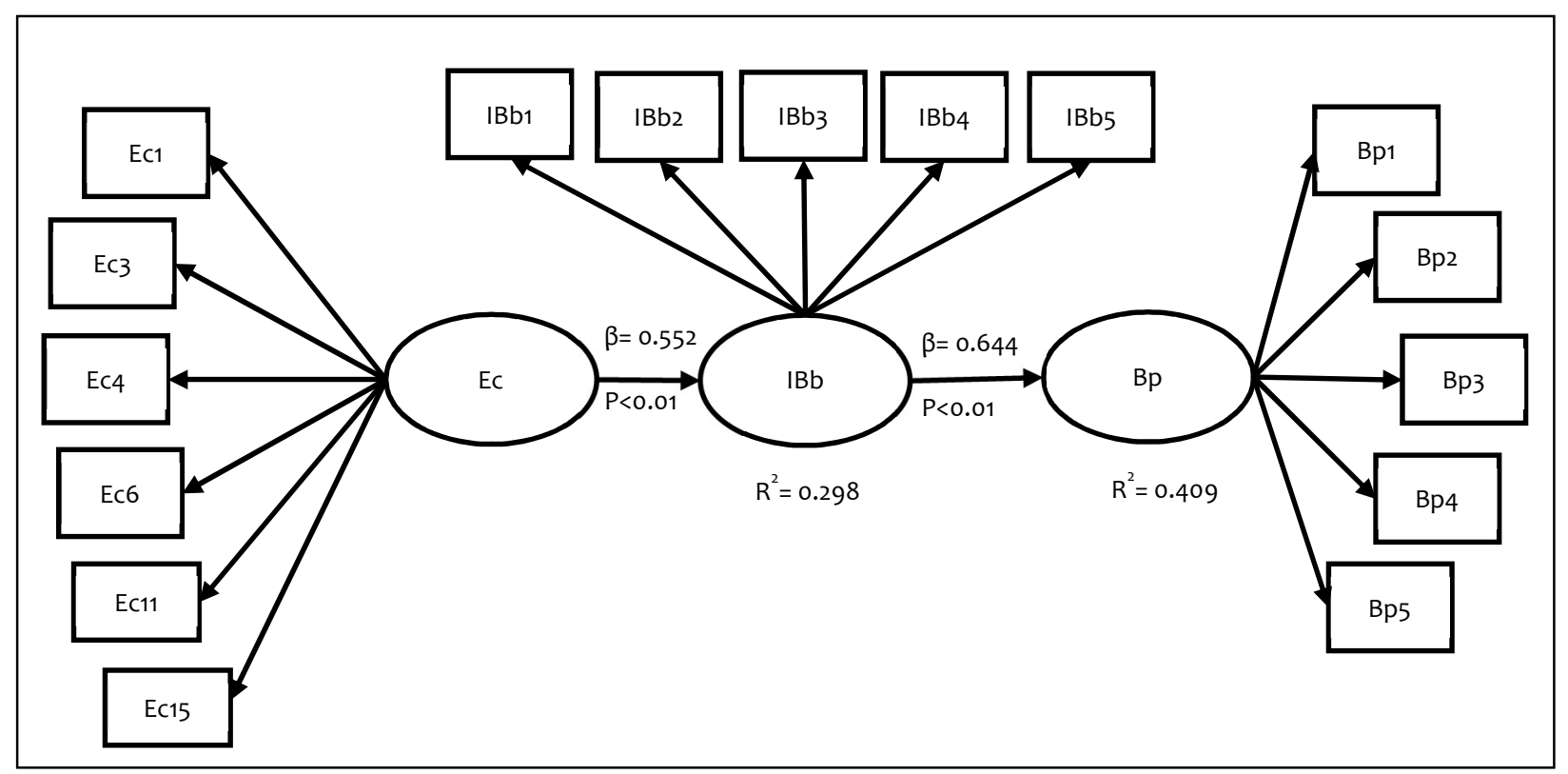

*Source: compiled by Authors.

Fig. 2. Significance of The Effect Relationship Across Variables in Path Diagram

Based on Table 9, the R-squared $\left(R^{2}\right)$ rate of the variance that affects Internet Technology-Based Business Application is 0,298. This rate can be described as that the variance of Entrepreneurship Competency has affected the variance of Internet TechnologyBased Business Application at the range of $29,8 \%$, while the remaining $70,2 \%$ is affected by other variables out of the research model. The variance that affects Business Performance has an Rsquared rate of 0,409 . This rate is elaborated as that the variances of Entrepreneurship Competency and Internet Technology-Based Business Application affects the variance of Business Performance at the range of $40,9 \%$, while the other $59,1 \%$ is affected by other variables beyond the research model. $R$-squared $\left(R_{2}\right)$ rate of the variance that affects Internet Technology-Based Business Application is in moderate category $(R 2>0,25)$, while the variablerate that affects Business Performance is in moderate category (R2>0,25) (Latan \& Ghozali, 2016).

The Q-Squaredrates for Internet Technology-Based Business Application and Business Performance are 0,309and 0,417 (>0), and thus, the research model has predictive relevance(Latan, \& Ghozali, 2016).

\subsubsection{Mediation Test}

he mediation test in this research uses Variance Accounted T For (VAF) Test. This method is suggested by Hair, Hult, Ringle, I and Sarstdett (2013) by motivation that it is more suitable or appropriate than others in testing mediation effect in PLS-SEM because PLS-SEM requires re-sampling method and there is no need for assumptions of variable distribution. Therefore, PLS-SEM can be applied in a small sample. Hair et al. (2013) state that mediation test procedure with VAF method involves the following steps:

1. The effect of the independent variable on the dependent variable is directly tested without involving the mediation variable.

2. If the direct effect is significant, then the procedure continues with testing the indirect effect of the independent variable on the dependent variable with the mediation variable.

3. If the indirect effect is significant, then it is followed by reckoning the VAF rate and determining whether the mediation effect has existed or not. This determination must regard some criteria of mediation as follows:

a. if the $V A F$ rate is $>80 \%$, there is full mediation;

b. if the condition is $20 \%<\mathrm{VAF}<80 \%$, then it is partial mediation;

c. if the VAF rate is $<20 \%$, there is no mediation effect.

The rate of Variance Accounted For (VAF) is reckoned by dividing the indirect effect with the total effect (direct effect plus indirect effect). The result of the test for both direct and indirect effects of the independent variable (Entrepreneurship Competency) on the dependent variable (Business Performance) through the mediation variable (Internet Technology-Based Business Application) is presented in Table 10.

Table 10 shows that both coefficients of direct effect and indirect effect are significant $(p<0,01)$ and their $\mathrm{VAF}$ rates are over $20 \%$. Therefore, it can be recognized that the mediation role of Internet Technology-Based Business Application is in the category of partial mediation in the relationship of Entrepreneurship Competency on Business Performance.

Table10

Testing on Mediation Role of Internet Technology-Based Business Application at the Effect of Entrepreneurship Competency on Business Performance using VAF Method ${ }^{*}$

\begin{tabular}{l|c|c}
\hline Description & Coefficient & P-Value \\
\hline Direct Effect & 0,61 & $<0,01$ \\
\hline Indirect Effect & 0,356 & $<0,01$ \\
\hline Total Effect & 0,966 & \\
\hline VAF Indirect Effect / Total Effect & 0,368 & \\
\hline
\end{tabular}

\footnotetext{
"Source: Primary data are processed (2018).
} 


\section{Discussion}

ome reasons why the city of Tarakan was chosen as research $\langle\mathbf{S}$ area are: a) the location of Tarakan city bordering Malaysia and Brunei Darussalam; it is potential for trade among countries as indicated in the city of Tarakan, many goods originating from Malaysia are imported, and conversely, there are many goods from Tarakan in Malaysia, b) Tarakan city is a stopover city and serves as an entry point for people from all regions of North Borneo (Bulungan regency, Nunukan Regency, Tana Tidung Regency, and Malinau regency), and c) Tarakan city is known as a service business city, which encourages the growth of SMEs more than other cities and districts in Northern Borneo. Furthermore, an explanation and discussion of the results of hypothesis testing are in this study.

\subsection{Entrepreneurship Competency and Internet Technology-Based Business Application}

able 9 and Fig. 2 show that there is an indication that T Entrepreneurship Competency has a positive and significant effect on Internet Technology-Based Business Application with a path coefficient value of 0,552 and a P-value of $<0,01$. This finding supports Hypothesis 1, and thus, this hypothesis is accepted. This finding is by Howcroft and Durkin (2000) who noted that entrepreneurship competency and entrepreneurship characteristics are factors that stimulate entrepreneurs to adopt internet technology into their business. Other previous studies also agree with this finding, such as McGowan and Durkin (2010), Ezenwafor et al. (2017) and Marti'ah (2017)adopting the internet for their business development. This research has proven that a high level of entrepreneurship competency is more encouraging entrepreneurs to adopt internet technology into their business activity. Entrepreneurs who often search and analyze information should have internet technology to get better and faster access to information about opportunities for a more profitable new business. Indeed, internet technology is also needed by entrepreneurs to build communication with customers to strengthen customer loyalty. Entrepreneurs can enhance their social network, especially with customers, via internet social media. The result of descriptive statistics has indicated that the usage level of internet technology is the highest when entrepreneurs build communication with customers. The second highest is when entrepreneurs use internet technology as a tool to promote their product and service.

\subsection{Internet Technology-Based Business Application and Business Performance}

able 9 and Fig. 2 show that Internet Technology-Based $\langle$ T Business Application has a positive and significant effect on Business Performance. Path coefficient value of this relationship is 0,644 with $p$-value $<0,01$. This finding justifies Hypothesis 2, and thus, this hypothesis is accepted. It corresponds with previous findings by Wade et al. (2004), McGowan and Durkin (2010), and Doherty et al. (2016). In general, their findings indicate that the adoption of internet technology makes business activity more efficient and helps entrepreneurs create a better business strategy and improve business performance. This research has proven that higher usage level of internet technology leads to improvement in business performance. The adoption of internet technology as tools of promotion and communication with customers should help increase customers' loyalty. The empowerment of customer loyalty will provide entrepreneurs with more sales and greater profits, which further increases the possibility of return on investment. The Internet is useful for business activity because it allows an online business transaction, which improves business operations' efficiency.

\subsection{Mediation Role of Internet Technology- Based Business Application at the Effect of Entrepreneurship Competency on Business Performance}

he direct effect of Entrepreneurship Competency on Business T Performance without the mediation of Internet TechnologyBased Business Application has been described in Table 10. The effect is positive and significant with a path coefficient value of 0.61 and $P$-value $<0,01$. Due to the finding of significant effect, the analysis continues to indirect effect testing. Result of the test shows that the indirect effect of Entrepreneurship Competency on Business Performance via Internet Technology-Based Business Application is positive and significant $(\mathrm{P}$-value $<0,001)$ with a path coefficient value of 0,356 . The next process was computing the VAF rate to determine whether there was a mediation effect or not. The reckoned VAF rate is above $20 \%$, which is precisely $36,8 \%$. Based on this result, the mediation role indeed exists. Internet Technology-Based Business Application plays the role of partial mediation at the effect of Entrepreneurship Competency on Business Performance. This finding corroborates Hypothesis 3, and thus, this hypothesis is accepted. This research has discovered that communication, promotion, sale, transaction, and supply distribution, which begin to get online, might work as a runway for entrepreneurship competency to improve sales, profit, customer loyalty, capitalization, and business efficiency. Partial mediation role of Internet Technology-Based Business Application can be realized as that entrepreneurship competency might help entrepreneurs achieve business success partially via internet technology. This finding should answer the research problem, respectively, whether entrepreneurship competency increases business performance via internet technology-based business application.

\section{Conclusions}

he objective of the research is to conduct a deep examination T of the effective relationship of internet technology-based entrepreneurship competency on the performance of Smalland-Medium Enterprises in the city of Tarakan. This research proposes three hypotheses.

The result of the hypothesis test on Hypothesis 1 indicates that the dynamic entrepreneurship competency affects entrepreneurs to adopt internet technology-based business applications. In other words, a high level of entrepreneurship competency leads to a high level of internet technology-based business application. This finding is under previous studies conducted by McGowan and Durkin (2010), Ezenwafor et al. (2017) and Marti'ah (2017).

The result of a hypothesis test on Hypothesis 2 has revealed that internet technology-based business applications can improve business performance. Therefore, a high level of internet technology-based business applications provides a higher level of business performance. This finding corresponds with previous studies carried out by Wade et al. (2004), McGowan and Durkin (2010)and Doherty et al. (2016).

The result of a hypothesis test on Hypothesis 3 explains that internet technology-based business application plays a mediation role in the effect of entrepreneurship competency on business performance. In other words, a high level of entrepreneurship competency is followed by a high level of both internet technology-based business application and business performance. The current research verifies that business-related activities, such as communication, promotion, sale, transaction, and supply distribution when they get online, can facilitate entrepreneurship competency to improve sales, profit, customer loyalty, capitalization, and business efficiency. Partial mediation role of Internet Technology-Based Business Application can be realized as that entrepreneurship competency might help entrepreneurs achieve business success partially via internet technology. This 
finding should answer the research problem, respectively, whether entrepreneurship competency does improve business performance via internet technology-based business application.

All aforementioned results have the practical implication that can be suggested to entrepreneurs who want to have a successful business. The results of this research have indicated that internet technology plays an important role in improving business performance, and therefore, entrepreneurs must integrate their competency and internet technology to run their business into a success. Small-and-Medium Enterprises, especially entrepreneurs, might find business opportunities widely opened when they use the internet, including the opportunity to improve business performance.

\section{Limitation}

he research has limitations; it only uses limited SME research $\langle$ T samples in the city of Tarakan; which is one of the small cities in Indonesia. Future research can expand the sample through other cities in Indonesia.

\section{References}

Ahmad, N. H., Suseno, Y., Seet, P.-S., Susomrith, P., \& Rashid, Z. (2018). Entrepreneurial Competencies and Firm Performance in Emerging Economies: A Study of Women Entrepreneurs in Malaysia: Springer International Publishing.

APJII. (2016). Penetrasi dan Perilaku Pengguna Internet Indonesia (Survey 2016), Polling Indonesia Asosiasi Penyelenggara Jasa Internet Indonesia.

Barazandeh, M., Parvizian, K., Alizadeh, M., \& Khosravi, S. (2015). Investigating the effect of entrepreneurial competencies on business performance among early stage entrepreneurs Global Entrepreneurship Monitor (GEM 2010 survey data). Journal of Global Entrepreneurship Research, 5(18), 1-12.

Barney, J. (1991). Firm resources and sustained competitive advantage. Journal of Management, 17(1), 99-121.

Camuffo, A., Gerli, F., \& Gubitta, P. (2012). Competencies matter: modeling effective entrepreneurship in northeast of Italy small firms. Cross Cultural Management, 19(1), 48-66.

Chaston, I., \& Mangles, T. (2003). Relationship marketing in online business-to-business markets. European Journal of Marketing, 37(5), 753-773.

Datta, \& R, P. (2005). Viral Marketing: New Form of Word-of-Mouth throug Internet. The Business Review, 3(2).

Doherty, E., Ramsey, E., Harrigan, P., \& Ibbotson, P. (2016). Impact of Broadband Internet Technologies on Business Performance of Irish SMEs. Strategic Change, 25, 693-716

Ezenwafor, J. I., Onokpaunu, M., \& Nna-Emmanuel, S. W. (2017). Rating Of Social Media Marketing Competencies Possessed By Entrepreneurs In Delta State, Nigeria. European Journal of Management and Marketing Studies, 2(1), 70-80.

Hair, J. F., Hult, G. T. M., Ringle, C., \& Sarstdett, M. (2013). A Primer on Partial Least Squares StructuralEquation Modeling (PLSSEM). Los Angeles: Sage.

Howcroft, B., \& Durkin, M. (2000). Reflections on bank-customer interactions in the new millennium. Journal of Financial Services Marketing, 5(1), 9-20.

Kemkominfo. (2016). Laporan Kinerja 2016. Jakarta: Kementerian Komunikasi dan Informatika.
Kraus, S., Rigtering, J. P. C., Hughes, M., \& Hosman, V. (2012). Entrepreneurial orientation and the business performance of SMEs: a quantitative study from the Netherlands. Review Managerial Science, 6(2), 161-182.

Latan, H., \& Ghozali, I. (2016). Partial Least Square Konsep, Metode dan Aplikasi Menggunakan WarpPLS 5.0. Semarang: Badan Penerbit Universitas Diponegoro.

Marti'ah, S. (2017). Kewirausahaan Berbasis Teknologi (Technopreneurship) dalam Perspektif Ilmu Pendidikan. Jurnal Ilmiah Edutic 3(2), 75-82.

McGowan, P., \& Durkin, M. G. (2010). Toward an Understanding of Internet Adoption at the Marketing/Entrepreneurship Interface. Journal of Marketing Management, 18, 361-377.

Meutiaa, \& Ismail, T. (2012). The Development of Entrepreneurial Social Competence And Business Network to Improve Competitive Advantage And Business Performance of Small Medium Sized Enterprises: A Case Study of Batik Industry In Indonesia. Procedia - Social and Behavioral Sciences 65, 46 - 51.

Mujiyana, Sularto, L., \& Mukhyi, M. A. (2012). Pengaruh Penerapan Periklanan DI Internet dan Pemasaran Melalui E-mail Produk UMKM dI Wilayah Depok. Jurnal TI Undip, VII(3), 161-168.

Pamela, Pambudy, R., \& Winandi, R. (2016). Kompetensi Kewirausahaan Dengan Keberhasilan Usaha Peternak Sapi Perah Pujon, Malang. Jurnal Agribisnis Indonesia, 4(1), 57-66.

Peterson, R. A., Balasubramanian, S., \& Bronnenberg, B. J. (1997). Exploring the Implications of the Internet for Consumer Marketing. Journal of the Academy of Marketing Science, 25(4), 329-346.

Prasad, V. K., Ramamurthy, K., \& Naidu, G. M. (2001). The Influence of Internet-Marketing Integration on Marketing Competencies and Export Performance. Journal of International Marketing, 9(4), 82-110.

Reimers, V., Chao, C. W., \& Gorman, S. (2016). Permission email marketing and its influence on online shopping. Asia Pacific Journal of Marketing and Logistics, 28(2), 308 -322.

Roblesa, L., \& Rodrigueza, M. Z. (2015). Key Competencies for Entrepreneurship. Procedia Economics and Finance, 23, 828 832.

Rosalind Jones, Alford, P., \& Wolfenden, S. (2015). Entrepreneurial Marketing in the Digital Age: A study of the SME tourism industry. Unpublished manuscript.

Sholihin, M., \& Ratmono, D. (2013). Analisis SEM-PLS dengan Warp PLS 3.0 untuk Hubungan Nonlinier dalam Penelitian Sosial dan Bisnis. Yogyakarta: Penerbit ANDI.

Sidik, I. G. (2012 ). Conceptual framework of factors affecting SME development: mediating factors on the relationship of entrepreneur traits and SME performance. Procedia Economics and Finance $4,373-383$.

Strauss, J., El-Ansary, A., \& Frost, R. (2003). E-Marketing. New York: Prentice Hall.

Sugiyono. (2012). Metode Penelitian Bisnis. Bandung: Alfabeta.

Wade, M., Johnston, D., \& McClean, R. (2004). Exploring the net impact of internet business solution adoption on SME performance. International Journal of Electronic Business, 2(4), 336-350.

Zahra, S. A., Filatotchev, I., \& Wright, M. (2009). How do threshold firms sustain corporate entrepreneurship? The role of boards and absorptive capacity. Journal of Business Venturing 24, 248-260. 